\title{
Koncentrace kortizolu ve slinách v průběhu zátěžových situací u úzkostných a neúzkostných adolescentů
}

\author{
Kateřina Kubíková1, Isabella Pavelková², Aneta Boháčová ${ }^{1}$ \\ ${ }^{1}$ Západočeská univerzita v Plzni, Fakulta pedagogická \\ ${ }^{2}$ Univerzita Karlova, Pedagogická fakulta
}

\begin{abstract}
Abstrakt: Cíle. Ve studii byla zkoumána biologická odezva organismu na zátěžové situace $v$ reálných situacích ve škole u adolescentů. Zjišt’ovaly jsme, jak se projevuje stresová reakce u jedinců neúzkostných a úzkostných. Hlavním cílem studie bylo tedy analyzovat změny v hladinách kortizolu obsaženého ve slinách v průběhu zátěžových situací ve škole.

Hypotézy. Analýzami stanovených hypotéz jsme ověřovaly, jak se mění hladina kortizolu v situacích spojených s hrozbou sociálního hodnocení ve školním prostředí u jedinců neúzkostných a úzkostných; H1a-c: Úzkostní jedinci budou ve všech sledovaných situacích vykazovat vyšší hladiny kortizolu ve srovnání s jedinci neúzkostnými. Dále jsme se zaměřily na možné souvislosti mezi tendencí jedince k úzkostnému prožívání a typem stresové reakce; H2: Úzkostní jedinci budou vykazovat odlišný vývoj hladiny kortizolu mezi situacemi A (vstup do školy), B (iniciace zátěžové situace) a C (skončení zátěžové situace) ve srovnání s jedinci neúzkostnými. Zabývaly jsme se rovněž odrazem strachu a úzkosti v hladinách kortizolu; H3: Úzkostní jedinci budou vykazovat ve výkonové situaci významné vazby mezi hladinou kortizolu a kognitivním a emocionálním strachem.

Metody. Výzkumný soubor tvořilo v první fázi studie 238 adolescentů. $V$ druhé fázi soubor pro analýzu slinného kortizolu tvořilo 38 participantů ve věku 12-14 let. Dotazníková baterie zahrnovala dotazník Piers-Harris II, sebeposuzovací dotazník B-JEPI a sebeposuzovací škálu TAI.

Výsledky. Z výsledků studie vyplývá, že u obou sledovaných skupin úzkostných a neúzkostných adolescentů má kortizol prokazatelně odlišný vývojový trend během dne. U úzkostných jedinců se projevila prokazatelně nižší hladina kortizolu při příchodu do školy oproti jedincům neúzkostným, u neúzkostných jedincủ s nízkou hladinou úzkostného prožívání jsme sledovaly vyšší hladinu kortizolu při prvním měření a pokles hladiny kortizolu ve slinách během dne. Z našich analýz vyplynulo, že silnější vztahy mezi kortizolem a testovou úzkostí vykazují zejména jedinci úzkostní ve srovnání s jedinci neúzkostnými.

Limitace. Hlavním omezením je menší výzkumný vzorek. Limitem výzkumu může být i výběr sledovaných situací, ve kterých byla hodnocena hladina kortizolu ve slinách. Významným limitem výzkumu je fakt, že první odběr proběhl $v$ různém čase po probuzení, poněvadž $v$ této části dne se hladiny kortizolu dynamicky mění.
\end{abstract}

Klíčová slova: škola, adolescent, kortizol, zátěžová situace, testová úzkost

\section{Salivary Cortisol Levels During Stressful Situation in Anxious Adolescents and Adolescents Without Anxiety}

Abstract: Objectives. We investigated the biological response of organism to stress in real situations at school in adolescents. We were interested in how stress is manifested in adolescents without anxiety and in adolescents with a tendency to anxiety experiencing. The aim of the study is to analyse changes in salivary cortisol levels during stressful situation at school. Hypotheses. The analyses verified how cortisol levels change in situations associated with the threat of social assessment in the school environment in individuals without anxiety and anxious; H1a-c: Anxiety individuals will have higher cortisol levels in all monitored situations compared to adolescents 
84 without anxiety. We also focused on the possible links between an individual's tendency to experience anxiety and the type of stress response; H2: Anxiety individuals will show a different development of cortisol levels between situations A, B and C compared to adolescents without anxiety. We also examined the relationships between cortisol levels and cognitive and emotional fear. $\mathrm{H} 3$ : Anxiety individuals will show significant links between cortisol levels and cognitive and emotional fear in the achievement situation.

Methods. The research group was comprised of 238 adolescents in the first phase of the study. The final sample for salivary cortisol analysis was comprised of 38 participants aged 12-14 years. The questionnaires battery contains Piers-Harris II, B-JEPI and TAI.

Results. The results show that in both groups of adolescents without anxiety and anxious adolescents, cortisol has a demonstrably different development trend during the day. Furthermore, anxious adolescents showed demonstrably lower cortisol levels at school compared to adolescents without anxiety, in adolescents without anxiety, we observed higher cortisol levels and fall of cortisol level during the day. Our analyses showed that stronger relationships between cortisol and test anxiety are shown especially by anxiety adolescents compared to adolescents without anxiety. Limitations. The limitation is a smaller research sample and the selection of situations in which the level of salivary cortisol was evaluated. The important limitation is the fact that the first sampling was taken at different times after awakening, because the cortisol levels change more dynamically in this part of the day.

Keywords: school, adolescents, cortisol, stressful situations, test anxiety

V posledních letech se středem pozornosti výzkumů v oblasti reakce člověka na stres stala analýza tzv. biomarkerů. Za jeden z hlavních biomarkerů ve výzkumu reakcí na stresové situace je považován kortizol (Hellhammer et al., 2009).

Biologická reaktivita na psychické stresory je navržena tak, aby připravila organismus na situace spojené s výzvou nebo hrozbou. Boyce a Ellis (2005) konstatovali, že senzitivita na stres není jednotný proces, ale zahrnuje regulační mechanismy, které slouží ke změně nebo zmírnění proživání fyziologického vzrušení. Právě tyto mechanismy se staly jedním z cílů zkoumání předkládané studie.

Za nejvýznamnější stresory v situacích spjatých s výkonem jsou u člověka považovány situace spojené se sociálním hodnocením. Právě sociální stresory se běžně používají k vyvolání stresové reakce, např. Trierův sociální stresový test (TSST; Kirschbaum et al., 1993) spolehlivě indukuje zvýšení kortizolu u člověka (např. Ellenbogen \& Hodgins, 2009; Gordis et al., 2006; Gunnar et al., 2009; Schultheiss et al., 2014). Řada studií se zdravými subjekty prokázala, že lze nalézt individuální rozdíly související se stylem zvládání stresové situace a předvídat díky tomu i různé úrovně hladin kortizolu (např. Kuhlman et al., 2019; Peters et al., 2011).

Individuální interpretace stresové situace nebo podnětu určuje, jak člověk na zátěžovou situaci reaguje. Zjednodušeně řečeno, reakce na zátěžovou situaci je modifikována jak typem sociální situace, tak individuálními charakteristikami jedince (Ellis et al., 2005; Sapolsky, 2002). Teorie naznačují, že se zvýšená vnímavost ve stresových situacích může odrážet v přehnaném vzrušení jak v podmínkách výzvy, tak i v situacích podpory a ochrany. Ovšem časté vystavování stresovým situacím může podle Thompsona (2014) ovlivnit fyziologický průběh vylučování a odbourávání kortizolu tak, že dojde k významnému narušení těch procesů, které regulují reakci organismu na stres. Z ontologického hlediska se vědci domnívají, že se v důsledku 
vývojové plasticity organismu v odpovědích na stres vytváří regulační mechanismy

určující způsob reakce na zátěžovou situaci zejména v dětském věku (Thompson, 2014). Právě toto zjištění nás vedlo k tomu, abychom se zamyslely nad tím, jak děti reagují na typickou stresovou situaci ve škole a jak se stresová odpověd’ organismu odráží v hladinách kortizolu měřeného ve slinách.

\section{Stres a hladiny kortizolu u dětí a dospívajících - přehled dosavadních poznatků}

V teoretických studiích nacházíme odkazy na výzkumy v oblasti dopadů dlouhodobého stresu na zdraví a psychický vývoj jedince v dětském věku. Dokazují, že př́liš brzké vystavení chronickému psychosociálnímu stresu může mít nepřiznivý vliv na zdraví (Hostinar \& Gunnar, 2013; Peters et al., 2011; Repetti et al., 2002, 2011). Děti vystavené stresovým vztahům nebo zkušenostem vykazují odlišné vzorce v produkci kortizolu ve srovnání s dětmi, které tyto stresující vztahy nebo zážitky nezažívají (Jaffee et al., 2015). Předpokládá se, že předchozí negativní zkušenosti dětí se odrážejí právě v sekreci kortizolu. Vyšší produkce kortizolu je spojována s nižšími úrovněmi poškození negativním stresem. Nejnižší úrovně reaktivity kortizolu se objevovaly u dětí poškozených negativními stresovými situacemi v předchozím roce. Řada studií zkoumala, jak děti reagují na akutní psychosociální stresory např. v TSST. U dětí ve věku 10-13 let bez negativní stresové minulosti se projevovalo významné zvýšení kortizolu v situacích měřených TSST, na rozdíl od dětí traumatizovaných předchozími negativními zkušenostmi (Ellenbogen \& Hodgins, 2009; Gordis et al., 2006; Gunnar et al., 2009).

Jen málo vědců zkoumalo, jak produkce kortizolu u dětí reaguje na akutní stresory v každodenním životě, i když je citlivá na denní výkyvy z psychosociálních zkušeností (Lippold et al., 2016a; Schultheiss et al., 2014; Sladek \& Doane, 2015). Zkoumání vazeb mezi stresem a kortizolem však může naznačovat, že opakované vystavování stresovým situacím přispívá $\mathrm{k}$ individuálním rozdílům v denních kortizolových rytmech u dětí. Tři publikované studie testovaly souvislosti mezi každodenními zkušenostmi a denní produkcí kortizolu u dětí a adolescentů. V první z nich Lippoldová a kolegové ukázali, že větší denní stres, včetně negativnějších interakcí mezi rodičem a dítětem, souvisel s vyššími hladinami kortizolu před spaním u 9-17letých dětí a adolescentů (Lippold et al., 2016a; Lippold et al., 2016b). Dále McHaleová et al. (2012) zjistili, že více času stráveného ve škole bylo v průměru spojeno s obecně nižšími hladinami kortizolu u 10-18letých dětí a adolescentů; trávit ve škole více času než obvykle však bylo spojeno u sledovaných dětí a adolescentů $s$ větším množstvím denní sekrece kortizolu. A negativní události ovlivnily hladiny kortizolu také následující ráno možná i částečně kvưli jejich dopadu na spánek (Chiang et al., 2016; Ly et al., 2015).

Stres související se školou je důležitým faktorem, který ovlivňuje rané dospívání. Vyšší úroveň stresu ve škole souvisí se zvýšeným počtem duševních problémů 
86 a s nižšími akademickými výsledky (Kaplan et al., 2005; Windle \& Windle, 2006). Několik studií ukázalo, že stresující školní a třídní atmosféra je spojená s vyšší celodenní produkcí kortizolu (Oberle \& Schonert-Reichl, 2016; Peters et al., 2011; Shirtcliff \& Essex, 2008; West et al., 2010). Výzkum provedený ve školním prostředí dokázal, že ve třídách, kde často dochází ke konfliktní komunikaci mezi učitelem a žáky, stoupá hladina kortizolu u dětí vždy během interakce s učitelem, zatímco ve třídách s nižším výskytem konfliktů dochází ke snižování kortizolové reakce během komunikace s učitelem (Lisonbee et al., 2008). Ve studii provedené u dospívajících bylo zjištěno, že u neoblíbených studentů s nižším akademickým prospěchem a s problematickým chováním se objevují vyšší hladiny kortizolu než u dětí prospívajících (West et al., 2010). Uskutečněné studie na druhé straně odhalily, že děti a adolescenti ve školním věku, kteři mají více problémů s vrstevníky, vykazují menší poklesy v hladinách kortizolu během dne a nižší ranní úrovně hladin kortizolu (Peters et al., 2011; Vaillancourt et al., 2008). Dospívající s konfliktnějšími vztahy se svými učiteli maji nižší rozdíly v hladinách kortizolu během dne než děti z více podpůrných školních prostředí (Ahnert et al., 2012). Na rozdíl od hodnocení denních změn v hladinách kortizolu testy ranních hladin kortizolu u dětí vedly $\mathrm{k}$ nekonzistentním výsledkům. Mezilidský stres, včetně problémů s vrstevníky a rodinných konfliktů, byl spjat s vyšši (Pendry \& Adam, 2007) a nižší (Slatcher \& Robles, 2012) hladinou ranního kortizolu.

Zajímavý výzkum (Kapsdorfer et al., 2018), který se mj. zabýval měřením hladiny kortizolu a jejích změn během školního dne u dětí s tendencí k úzkostnému chování a dětí neúzkostných přímo $v$ reálných situacích během školního dne, naznačil, že hladiny kortizolu se mění během dne s ohledem na prožívanou situaci u dětí s různou tendencí k úzkostnému prožívání. Dále se projevily významně vyšší koncentrace kortizolu ve slinách během stresových situací v celé sledované skupině (tedy jak u dětí úzkostných, tak u dětí neúzkostných). Analýzy naznačily, že pokles hladiny kortizolu během školního dne byl statisticky významný u skupiny úzkostných dětí během zátěžové situace. $V$ neposlední řadě se $v$ tomto výzkumu ukázalo, že úzkostné děti vykazovaly vyšší hladiny kortizolu na začátku vyučovacích hodin, což by mohlo naznačovat zvýšené napětí a stresové prožívání zátěžové situace.

$V$ současné době se u nás i ve světě klade značný důraz na výsledky v souhrnných didaktických testech (maturita, přijímací zkoušky apod.). Tyto výstupy jsou měřítkem akademické úspěšnosti a mají vliv na budoucí studijní kariéru jedince, což jen potvrzuje význam zkoumání vlivu emocí na výkon jedince. Zajímavou a dosti studovanou oblastí projevů emocí ve školním prostředí je tzv. testová úzkost. V roce 1988 publikoval Ray Hembree rozsáhlou analýzu 562 studií věnující se příčinám, účinkům a možnostem prevence testové úzkosti. Tato práce měla velký dopad na následné pochopení mechanismů vzniku testové úzkosti a zejména na identifikaci individuálních zvláštností, např. s ohledem na věk, pohlaví nebo etnicitu a na jejich vztahy (např. typické spojení s nižším akademickým výkonem). V empirických studiích je obecně uznáváno, že testová úzkost se skládá ze dvou složek - obavy (odvrácení pozornosti od testu samotného, vtíravé myšlenky) a emocionality (vegetativní přiznaky úzkosti, bušení srdce, nauzea) v testové situaci - a bývá spjata např. s kognitivní 
interferencí, projevuje se špatnými studijními dovednostmi a tendencí k vyhýbání se výkonové situaci (Zeidner et al., 2008). Testovou úzkost lze obecně popsat jako všudypř́tomnou formu akademické úzkosti, která má obecně negativní dopad na vzorce víry v sebe sama a chování ve zkouškových situacích (Cassady, 2010).

Výzkum v oblasti testové úzkosti se opakovaně prováděl v souvislosti s výkonnostními výsledky $v$ akademických podmínkách, přičemž konzistentní zjištění ilustrují, že negativní dopad na výkonnost se projevil u studentů s projevy testové úzkosti (DeCaro et al., 2011; Lowe et al., 2011). Studenti se setkávají s testovou úzkostí ve všech fázích cyklu učení a testování. Výzkumy dokazují, že se testová úzkost projevuje během př́pravy testu (Cassady, 2004b), výkonem během testu (Ramirez \& Beilock, 2011), fází reflexe testu (Sommer \& Arendasy, 2014; Thomas \& Gadbois, 2007), a dokonce i v laboratorních experimentech v situacích, které neměly bezprostřední hodnotící dopad (Cassady, 2004a). Problém v uchopení a přesném popisu testové úzkosti je tedy $v$ její individuální variabilitě projevů, a tudíž je nutné ji chápat jako multifaktoriální konstrukt závislý na biologických, psychologických a sociálních proměnných (Sommer \& Arendasy, 2014). Patří k ní také intrapersonální proměnné, kupř. motivace a seberegulace (Dull et al., 2015; Khalaila, 2015; Schnell et al., 2015), sociální vlivy (očekávání a hodnoty výkonu, standardy úspěchu a sociální podpora; Ringeisen \& Raufelder, 2015; von der Embse et al., 2018) nebo demografické proměnné (úroveň vzdělání, ekonomický status a kulturní pozadí; Hembree, 1988; Putwain, 2008; Zeidner et al., 2008).

Výše zmíněné studie zabývající se projevy dlouhodobého stresu ve změnách hladin kortizolu ve stresových situacích však v dostatečné míře neodpovídají na otázku, jak se reálná výkonová a často se ve škole opakující situace spojená s hrozbou sociálního hodnocení projevuje v hladinách kortizolu s ohledem na individuální zvláštnosti dětí. Po důkladné rešerši dostupných studií zjišt'ujeme, že výzkumné sondy byly prováděny bud' v přesně nasimulovaných situacích (viz např. TSST; Jaffee et al., 2015; Schultheiss et al., 2014), anebo v podobě odběrů vzorků kortizolu během školního dne (kupř. Slatcher \& Robles, 2012; Vaillancourt et al., 2008), proto jsme se rozhodly na pilotní studii ověřit, zda a do jaké míry se odráží stres v hladinách kortizolu u dětí během reálné výkonové situace ve škole. Biologická analýza reakcí dětí v reálném prostředí nám přinese nové poznatky zejména proto, že jde o zkoumání v situaci, kdy dochází ke spojení sociálního hodnocení s výkonem a prožitkem, což žáci často vztahují ke svým kompetencím, sebepojetí a tvorbě perspektivní orientace (písemný test navazuje jak na žákovy dřivější zkušenosti, tak výsledek do jisté míry předjímá dění v budoucnosti - známka na vysvědčení, reakce rodičů, přijímací zkoušky apod.; podrobněji viz Hrabal \& Pavelková, 2010). 
Analýza zkušeností spojených se stresem a výkonem a jejich odraz v hladinách kortizolu u adolescentů nás vedly $\mathrm{k}$ myšlence hlouběji analyzovat chování adolescentů během reálné zátěžové situace ve škole. Hledaly jsme odpovědi na otázky, zda tendence k úzkostnému prožívání má vliv na typ stresové reakce a vyrovnávání se s ní.

Jak již bylo řečeno, koncentrace hormonů nejsou často měřeny $v$ reálných situacích, ale spíše v simulovaných situacích, bud' v psychologických laboratořích, nebo během speciálně připravených experimentů, proto se může kortizolová odpověd' organismu v simulované a ve skutečné situaci lišit (Jaffee et al., 2015; Oberle \& Schonert-Reichl, 2016; Peters et al., 2011).

Představujeme pilotní studii, $v$ niž v souladu s výše zmíněnými teoriemi zkoumáme biologickou odezvu organismu na zátěžové situace $v$ reálných výkonových situacích ve škole spojených s hrozbou sociálního hodnocení u adolescentů s různou tendencí k úzkostnému proživání, a přispíváme tak do diskuse $\mathrm{k}$ tomuto tématu.

\subsection{Výzkumný vzorek a sběr dat}

Cílem výzkumu bylo zjistit, jak reagují adolescenti úzkostní a neúzkostní na potenciálně zátěžové situace ve škole. Vzhledem $\mathrm{k}$ tomuto cíli byl výzkum rozdělen do dvou fází.

První fáze, která proběhla v listopadu 2018, se zúčastnilo 238 adolescentů (12-14 let) ze čtyř základních škol náhodně vybraných v Plzeňském kraji (Česká republika). Výběr proběhl opakovaným losováním, dokud nebyl získán souhlas oslovených škol s provedením výzkumu. $\mathrm{K}$ účasti byli osloveni všichni žáci 8 . tříd participujících škol (celkem 256). V den započetí výzkumu (první fáze) všichni př́tomní účastníci vyplnili dotazníky měřící rysovou úzkost (B-JEPI, Piers-Harris II). Probandi byli řádně poučeni, jak s nástroji pracovat, a měli dostatek času na vyplnění. Výsledky všech testů byly vyhodnoceny a jednotliví probandi byli rozděleni do dvou skupin. $\mathrm{K}$ tomu bylo třeba, aby respondenti jednoznačně skórovali bud' jako úzkostní, nebo jako neúzkostní ve škálách B-JEPI a Piers-Harris II a aby jejich rodiče poskytli souhlas $\mathrm{s}$ účastí adolescenta $v$ druhé fázi výzkumu (odběr slin $\mathrm{k}$ určení hladiny kortizolu). $Z$ celkového počtu 136 adolescentů, kteří splnili uvedená kritéria, bylo losováním vybráno 20 tzv. rysově úzkostných adolescentů (splňujících v obou použitých dotaznících kritérium úzkostnosti; dívky $N=10$, hoši $N=10$ ) a 20 neúzkostných jedinců (skórujících v obou dotaznících pod kritérium úzkostnosti; dívky $N=10$, hoši $N=10$ ) $z$ deseti školních tříd a čtyř škol. Losování proběhlo tak, že z každé participující třídy byli (z těch, kteří splnili kritéria) vybráni maximálně dva adolescenti úzkostní a dva neúzkostní, a to $z$ toho důvodu, aby byl zajištěn hladký průběh sběru dat pedagogy/ asistenty pedagoga.

V druhé fázi výzkumu, která proběhla $v$ lednu 2019, byly odebrány $\mathrm{v}$ jednotlivých zátěžových situacích každému ze 40 účastníků tř̌i vzorky slin $\mathrm{k}$ analýze hladiny kortizolu (viz níže). Dva probandi byli pro neprůkaznost odebraných vzorků z výzkumu 
vyřazeni. Finálně tedy bylo analyzováno 114 vzorků odebraných od 38 participantů

( $N=19$ úzkostných, $N=19$ neúzkostných). Všechny děti, které se účastnily druhé fáze výzkumu, na závěr výzkumu vyplnily dotazník TAl.

Potenciálně zátěžové situace ve škole byly pro všechny participanty stejné, vždy se jednalo o předem neohlášený test $z$ matematiky $v 8$. ročníku základní školy. Probandi neměli informace o tom, kdy odběry proběhnou, o odběrech se dozvěděli až $v$ průběhu prvního odběru. Vzorky byly odebírány vždy stejným způsobem ve třech situacích. První odběr proběhl inned po příchodu do školy (situace $A$ ), okolo 7.45 hodin ráno. Tento odběr sloužil pro zjištění výchozí hladiny kortizolu a následné zhodnocení změn. Druhý odběr proběhl při iniciaci školní zátěžové situace, tj. na začátku neohlášeného testu z matematiky - konkrétně bezprostředně po zadání testu (situace B). Test z matematiky byl vždy zadán na začátku vyučovací hodiny učitelem/ učitelkou matematiky a trval vždy polovinu vyučovací hodiny - zhruba 25 minut. Třetí odběr proběhl po ukončení zátěžové situace - ihned po odevzdání testu z matematiky (situace C). Časový rozestup mezi situací A a B byl max. 30 minut, odběry vždy probíhaly první vyučovací hodinu. Rozestup mezi situací B a C byl také max. 30 minut. Vzorky tedy byly odebírány během reálných situací ve škole, a to asistenty učitelů a učiteli, kteří byli dopředu proškoleni, jakým způsobem vzorky odebírat. Autorky studie odběry neprováděly $z$ toho důvodu, aby nenarušily zaběhlý režim ve školní třídě, a neovlivnily tak výsledky šetření. Odběry biologických materiálů probíhaly vždy stejným způsobem. Adolescentům byl do úst vložen vatový tamponek, který byl napuštěn kyselinou trikarboxylovou pro podporu slinění. Tamponek žáci ponechali po dobu jedné minuty v ústech a následně vyplivli do zkumavky. Zkumavky byly co nejrychleji zmrazeny a uchovávány při teplotě $-20{ }^{\circ} \mathrm{C}$.

Po posledním odběru kortizolu (situace $C$ ) všichni sledovaní žáci vyplnili dotazník testové úzkosti TAl.

\subsection{Výzkumné nástroje}

Rysová úzkost (osobnostní tendence zažívat úzkost) byla měřena dotazníkem B-JEPI a dotazníkem Piers-Harris II, testová úzkost dotazníkem TAI.

Dotazník sebepojetí dětí ve vztahu k důležitým aspektům života Piers-Harris II. Dotazník, který je v anglosaské literatuře znám pod názvem Piers-Harris Children's Self-Concept Scale (PHCSCS), sestavili Ellen V. Piersová a Dale B. Harris (1964). Dotazník byl dále revidován a rozšiřován (Piers \& Herzberg, 2002), námi použitá podoba prošla v USA velmi podrobnou ověřovací analýzou na reprezentativním vzorku napříč kontinentem, nástroj byl finálně doporučen pro probandy ve věku 9-18 let. Česká verze dotazníku Piers-Harris II byla standardizována na vzorku 2600 žáků (Orel et al., 2015). Dotazník v české verzi zahrnuje stejné subškály sebepojetí a validizační škály jako původní nástroj. Subškály sebepojetí dohromady tvoří celkový skór (TOT - Total score), který je mírou celkového sebepojetí respondenta. Dále test zahrnuje šest subškál, které hodnotí specifické oblasti sebepojetí: přizpůsobivost 
90 (BEH - Behavioral Adjustment), intelektové a školní postavení (INT - Intellectual and School Status), fyzický zjev (PHY - Physical Appearance and Attributes), nepodléhání úzkosti (FREE - Freedom from Anxiety), popularitu (POP - Popularity), štěstí a spokojenost (HAP - Happiness and Satisfaction). Validizační škály zahrnují index inkonzistentních odpovědí (IRI), který má odhalit náhodný výběr odpovědí, a index převažujících odpovědí (RES), který měří tendenci jedince odpovídat ano, nebo ne bez ohledu na obsah položky (Orel et al., 2015). Nízké skóre v určité subškále vyjadřuje negativnější sebepojetí a sebehodnocení, vyšší skóre naopak pozitivnější sebepojetí a sebehodnocení $v$ dané oblasti. $V$ souladu s designem výzkumu jsme se zaměřily zejména na výsledky probandů ve škále FREE. Hodnoty, které v přepočtu na standardní skóre byly nižší než 6, vymezily adolescenty se zvýšenou úzkostí.

Sebeposuzovací dotazník B-JEPI. Eysenck vytvořil dotazník B-JEPI (Junior Eysenck Personality Inventory) v roce 1987 (Svoboda et al., 2015). Tento dotazník vznikl přepracováním původního dětského dotazníku JEPI z roku 1965. Dotazník B-JEPI je tvořen třemi dimenzemi osobnosti a subškálou tzv. lživých odpovědí. Škála P znázorňuje psychoticismus, škála $\mathrm{E}$ - extroverzi, škála $\mathrm{N}$ - neuroticismus, škála $\mathrm{L}$ - L-skór disimulace. Českou verzi dotazníku připravil a ověril J. Senka (1994), dotazník obsahuje 78 položek. Nástroj je možné zadávat jak skupinově, tak individuálně. Respondent u jednotlivých otázek zakroužkuje bud' odpověd” „ano“, nebo „ne“. V souladu s designem výzkumu jsme sledovaly výsledky probandů ve škále N. Hodnoty, které byly stejné nebo vyšší než průměr + směrodatná odchylka, vymezily adolescenty se zvýšenou úzkostností. Pro tento způsob jsme se rozhodly také proto, že normy pro českou populaci jsou již zastaralé.

Sebeposuzovací škála TAI. Dotazník testové úzkosti TAl je př́mo zacílen na identifikaci obav a emocionality během testové situace. Spielberger (1980) vyvinul sebehodnoticí stručnou škálu TAI, která byla vytvořena pro měření obou faktorů testové úzkosti, přičemž ji navrhl speciálně pro měření úzkosti adolescentů a vysokoškolákủ. Obsahuje dvě podskupiny: test úzkostných obav (TAI-W) a test úzkosti emoční (TAI-E). Osm položek inventáře měří úzkostné obavy TAI-W, osm pro zjišt'ování TAI-E. Respondenti odpovídají na Likertově čtyřbodové stupnici: 1) téměř nikdy, 2) někdy, 3) často a 4) téměř vždy. Česká verze nástroje TAl vykazuje velmi kvalitní psychometrické vlastnosti a je možné ji používat $\mathrm{i} v$ dolních hranicích doporučené věkové normy (Kubíková et al., 2018).

\subsection{Analýza hladin kortizolu ve slinách}

Úroveň prožívaného stresu u žáků byla zjišt’ována tak, že se odebíral vzorek slin k změření hladiny kortizolu (Dabbs, 1991). Vzorky slin byly odebrány do speciálních zkumavek s bavlněnými tamponky napuštěnými kyselinou citronovou (Salivette, Sarstedt, Velká Británie). Probandi byli instruováni žvýkat tamponek po dobu jedné minuty a poté ho vyplivnout zpět do zkumavky. Analýza sebraného biologického materiálu probíhala v laboratořích VŠCHT v Praze následujícím způsobem. Před analýzou byly sliny rozmrazeny, zcentrifugovány (13000 g, 10 minut) a do čisté 
zkumavky bylo odebráno $0,5 \mathrm{ml}$ supernatantu. Následně bylo přidáno $10 \mu \mathrm{l}$ roztoku methyltestosteronu ( $c=25 \mathrm{ng} / \mathrm{ml}$ ) jako vnitřní standard a $0,5 \mathrm{ml}$ vody. Po promíchání byl roztok extrahován $2 \mathrm{ml}$ a následně $1,5 \mathrm{ml}$ diethyletheru. Organické vrstvy byly odebrány do čisté zkumavky, odpařeny a zbytek byl rozpuštěn ve $100 \mu$ l roztoku methanolu $(20 \% \mathrm{v} / \mathrm{v})$.

Hladiny kortizolu ve vzorcích byly stanoveny pomocí kapalinové chromatografie s hmotnostní detekcí za použití prístroje UHPLC Agilent 1290 Infinity s detektorem typu trojitý kvadrupól Agilent $6460 \mathrm{~s}$ ionizací elektrosprejem a chromatografickou kolonou Zorbax Eclipse Plus Phenyl-Hexyl RRHD, 2,1 × $100 \mathrm{~mm}, 1,8 \mu \mathrm{m}$ (Agilent Technologies). Použita byla gradientová eluce mobilních fází $1 \mathrm{mM}$ fluorid amonný a směs acetonitril/methanol $(75 / 25 \mathrm{v} / \mathrm{v})$. Ionizace pro hmotnostní detekci probíhala v pozitivním modu.

\subsection{Statistická analýza}

Výsledný soubor pro analýzu tvořilo 38 participantů, žáků 8. tříd spolupracujících základních škol, ve věku 12-14 let, z toho 18 dívek a 20 chlapců, vzorky dvou dívek (1 ze skupiny úzkostných, 1 ze skupiny neúzkostných) nebylo možné analyzovat, proto byly ze studie vyřazeny.

Rozdíly $v$ hladině kortizolu $v$ jednotlivých situacích mezi skupinami úzkostných a neúzkostných participantů byly zjišt’ovány neparametrickým Mann-Whitneyovým testem. Předpokládaly jsme, že úzkostní jedinci budou ve všech situacích vykazovat vyšší hladiny kortizolu ve srovnání s jedinci neúzkostnými (H1a-c). Rozdíly mezi skupinami ve vývoji hladiny kortizolu mezi situacemi $\mathrm{A}, \mathrm{B}$ a $\mathrm{C}$ byly testovány analýzou rozptylu pro opakovaná měření (repeated measures ANOVA) s Bonferroniho post-hoc testy. Měly jsme za to, že úzkostní jedinci budou vykazovat odlišný vývoj hladiny kortizolu mezi situacemi A, B a C ve srovnání s jedinci neúzkostnými $(\mathrm{H} 2)$. Vztah mezi kognitivním a emocionálním strachem $v$ testové situaci a hladinou kortizolu byl analyzován Spearmanovým korelačním testem. Domnívaly jsme se, že úzkostní jedinci budou vykazovat ve výkonové situaci významné vazby mezi hladinou kortizolu a kognitivním a emocionálním strachem $(\mathrm{H} 3)$. Data byla zpracována ve statistickém programu jamovi (The jamovi project, 2019) a $R$ (R Core Team, 2018).

\subsection{Etika výzkumu}

Účast ve výzkumu byla dobrovolná a striktně anonymní, souhlasy zákonných zástupců nezletilých účastníků studie jsou $\mathrm{k}$ dispozici u autorek výzkumu. Všichni účastníci výzkumu byli pečlivě proškoleni o metodách a cílech studie, účast $v$ něm byla zcela dobrovolná. Data analyzovaná ve studii byla zpracována v souladu s GDPR. 


\section{Výsledky výzkumu}

\subsection{Rozdíly v hladině kortizolu mezi úzkostnými a neúzkostnými jedinci}

Tabulka 1 uvádí naměřené hodnoty pro všechny sledované proměnné. Úzkostní a neúzkostní participanti se statisticky významně lišili v hladině kortizolu při příchodu do školy (kortizol A). $V$ př́padě hladin kortizolu na začátku a na konci testové situace se již statisticky významné rozdíly mezi skupinami nepodařilo prokázat. $V$ rozporu s naším očekáváním, které bylo testováno v H1a-c, však úzkostní jedinci vykazovali ve všech situacích nižší hladinu kortizolu oproti jedincům neúzkostným.

Tabulka 1 Hladiny kortizolu v jednotlivých situacích a kognitivní a emocionální strach u úzkostných $(N=19)$ a neúzkostných $(N=19)$ jedinců

\begin{tabular}{|c|c|c|c|c|c|c|c|}
\hline & \multicolumn{2}{|c|}{ Úzkostní } & \multicolumn{2}{|c|}{ Neúzkostní } & \multirow{2}{*}{$\begin{array}{l}\text { Průměrný } \\
\text { rozdíl }\end{array}$} & \multirow{2}{*}{$\begin{array}{c}\text { Mann- } \\
\text { Whitney U/ } \\
\text { Welch } t\end{array}$} & \multirow{2}{*}{ Cohen $d$} \\
\hline & průměr & $S D$ & průměr & $S D$ & & & \\
\hline COR_A (ng/ml) & 1,12 & 0,94 & 3,90 & 2,53 & $-2,30$ & $39,01^{* * *}$ & $-1,48$ \\
\hline COR_B (ng/ml) & 1,69 & 1,62 & 2,73 & 2,14 & $-0,84$ & 114,03 & $-0,55$ \\
\hline COR_C $(\mathrm{ng} / \mathrm{ml})$ & 1,65 & 1,21 & 2,50 & 2,35 & $-0,32$ & 150,02 & $-0,46$ \\
\hline $\begin{array}{l}\text { Kognitivní strach } \\
(\text { TAl-W })^{\mathrm{a}}\end{array}$ & 15,95 & 2,72 & 18,84 & 4,37 & $-2,90$ & $-2,45^{*}$ & $-0,80$ \\
\hline $\begin{array}{l}\text { Emocionální } \\
\text { strach }(\text { TAl-E) }\end{array}$ & 16,36 & 3,25 & 20,74 & 5,04 & $-4,47$ & $-3,25^{* *}$ & $-1,06$ \\
\hline
\end{tabular}

${ }^{a}$ Rozdíly byly zjišt’ovány Welchovým $t$-testem (stupně volnosti pro TAI-W = 30,1, TAI-E = 30,7). COR_A = hladina kortizolu při vstupu do školy, COR_B = hladina kortizolu při iniciaci zátěžové situace, COR_C = hladina kortizolu po skončení zátěžové situace.

${ }^{*} p<0,05 ;{ }^{* *} p<0,01 ;{ }^{* * *} p<0,001$

\subsection{Rozdíly ve vývoji hladiny kortizolu mezi úzkostnými a neúzkostnými žáky}

Předpokládaly jsme, že vývoj hladiny kortizolu během školního dne bude u úzkostných žáků odlišný oproti žákům neúzkostným. Tento předpoklad jsme ověřovaly analýzou rozptylu pro opakovaná měření. Odpovídající testovanou hypotézu H2 potvrdily statisticky významné interakce mezi skupinou (úzkostní versus neúzkostní) a situací, při níž byl odebírán kortizol (A versus $B$ versus $C$ ): $F(2,72)=8,77, p<0,001$. Odlišnost vývoje hladin kortizolu u úzkostných a neúzkostných adolescentů ve sledovaných situacích $A, B, C$ je zachycena rovněž v obrázku 1 . Z obrázku 1 je patrné, že úzkostní jedinci vykazovali nižší hodnoty kortizolu při vstupu do školy (A), hladina jejich kortizolu stoupala při iniciaci zátěžové situace (B) a po skončení zátěžové situace (C) zůstávala zhruba na stejné úrovni. Post-hoc testy (tabulka 2) ukazují, že 
rozdíly v hladině kortizolu mezi situacemi $\mathrm{A}, \mathrm{B}$ a C u úzkostných adolescentů nejsou statisticky významné. U skupiny neúzkostných jedinců jsme naopak zaznamenaly relativně nejvyšší hladinu kortizolu při vstupu do školy $(A)$ a nižší hladiny kortizolu při iniciaci testové situace $(B)$ a po jejím skončení $(C)$. Rozdíl mezi hladinou kortizolu v situaci $\mathrm{A}$ a $\mathrm{B}$, resp. A a $\mathrm{C}$, byl u neúzkostných jedinců statisticky významný. Na rozdíl od úzkostných jedinců tedy neúzkostní jedinci vykázali významný pokles $v$ hladině kortizolu mezi prvním měřením při příchodu do školy $(A)$ a měřeními při iniciaci zátěžové situace $(B)$ a po jejím skončení $(C)$.

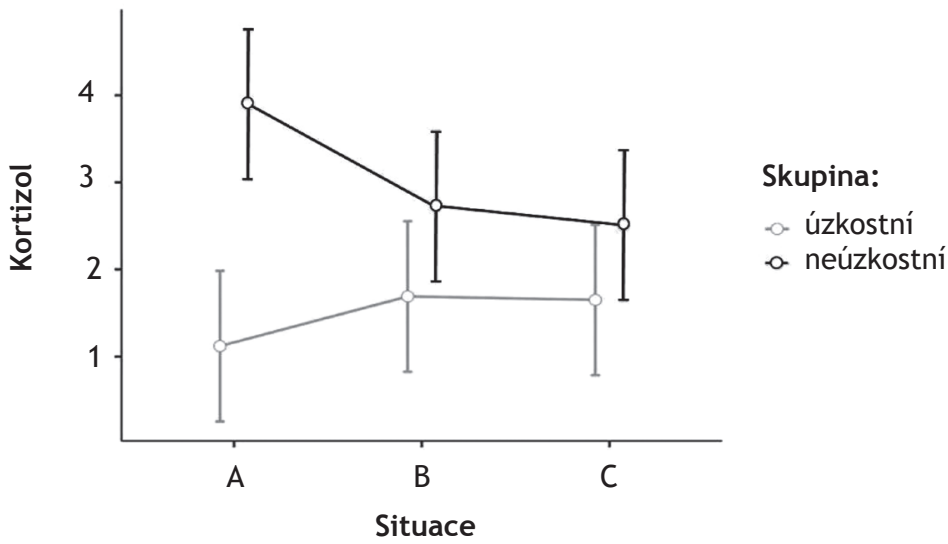

Obrázek 1 Hladina kortizolu u úzkostných a neúzkostných jedinců v průběhu školního dne. Poznámka: $A$ = hladina kortizolu při vstupu do školy, $B$ = hladina kortizolu při iniciaci zátěžové situace, $\mathrm{C}=$ hladina kortizolu po skončení zátěžové situace.

Tabulka 2 Rozdíly v hladinách kortizolu mezi jednotlivými situacemi (A, B, C) u úzkostných $(N=19)$ a neúzkostných $(N=19)$ jedinců

\begin{tabular}{lcccccc}
\hline & \multicolumn{3}{c}{ Úzkostní } & \multicolumn{3}{c}{ Neúzkostní } \\
\cline { 2 - 7 } & $\begin{array}{c}\text { průměrný } \\
\text { rozdíl }\end{array}$ & $t$ & Cohen $\boldsymbol{d}$ & $\begin{array}{c}\text { průměrný } \\
\text { rozdíl }\end{array}$ & $t$ & Cohen $\boldsymbol{d}$ \\
\hline COR_A - COR_B & $-0,57$ & $-1,59$ & $-0,37$ & 1,17 & $3,27^{*}$ & 0,62 \\
COR_A - COR_C & $-0,53$ & $-1,48$ & $-0,43$ & 1,39 & $3,88^{* *}$ & 0,67 \\
COR_B - COR_C & 0,04 & 0,11 & 0,03 & 0,22 & 0,61 & 0,17 \\
\hline
\end{tabular}

Poznámka: Stupně volnosti pro všechny analýzy = 72,0. Standardní chyba $(S E)$ pro všechny analýzy $=0,358$. COR_A = hladina kortizolu při vstupu do školy, COR_B = hladina kortizolu při iniciaci zátěžové situace, COR_C = hladina kortizolu po skončení zátěžové situace.

${ }^{*} p<0,05 ;{ }^{* *} p<0,01 ;{ }^{* * *} p<0,001$ 


\subsection{Vztah mezi strachem a hladinou kortizolu}

V další fázi jsme zkoumaly, zda žáky reportovaný kognitivní a emocionální strach souvisí s naměřenými hladinami kortizolu (tabulka 3). Zaměřily jsme se zejména na vztah mezi kognitivním a emocionálním strachem a hodnotami kortizolu C, protože jeho sběr proběhl časově nejbliže se zjišt’ováním strachu (vyplňováním dotazníku TAI). Prostřednictvím Spearmanova neparametrického korelačního testu jsme zjistily středně silný a statisticky významný vztah mezi hladinou kortizolu a kognitivním strachem $v$ celém souboru $(\rho=0,45, p=0,01)$. Vztah se přitom jeví silnější u úzkostných jedinců (obrázek 2), což podporuje i Spearmanův koeficient korelace naměřený pouze u skupiny úzkostných žáků $(\rho=0,49, p=0,03)$, a naopak nižší a statisticky nevýznamný koeficient korelace naměřený u skupiny neúzkostných žáků ( $\rho=0,30$, $p=0,22$ ). Vztah mezi kortizolem a emocionálním strachem se prokázal na celém souboru žáků ve výkonové situaci $(B), t j$. při zadání testu, ovšem jedná se o slabší vazbu $(\rho=0,36, p=0,04)$. Silnější vazby emocionálního strachu a hladiny kortizolu jsou ž̌etelné u skupiny úzkostných žáků v situacích $\mathrm{B}$ - zadání testu a $\mathrm{C}$ - po skončení testu (viz TAl-E yes) oproti žákům neúzkostným, u nichž nebyly prokázány žádné významné vztahy (viz TAl-E no). Výstupy tedy podporují předpoklady formulované v hypotéze H3, tj. že úzkostní jedinci vykážou v zátěžových (výkonových) situacích významné vazby mezi hladinou kortizolu a kognitivním a emocionálním strachem.

Tabulka 3 Spearmanovy korelační koeficienty mezi hladinami kortizolu, kognitivním a emocionálním strachem $(N=38)$

\begin{tabular}{llcccccccc}
\hline & & COR_B & COR_C & TAI-W & TAI-E & $\begin{array}{c}\text { TAI-W } \\
\text { yes }\end{array}$ & $\begin{array}{c}\text { TAI-W } \\
\text { no }\end{array}$ & $\begin{array}{c}\text { TAl-E } \\
\text { yes }\end{array}$ & $\begin{array}{c}\text { TAI-E } \\
\text { no }\end{array}$ \\
\hline COR_A & $\rho$ & 0,62 & 0,45 & 0,40 & 0,30 & 0,12 & 0,43 & 0,02 & 0,01 \\
& $p$ & $<, 01$ & $<, 01$ & $<, 05$ &, 07 &, 62 &, 07 &, 93 &, 96 \\
COR_B & $\rho$ & - & 0,83 & 0,42 & 0,36 & 0,53 & 0,06 & 0,42 & 0,00 \\
& $p$ & - & $<, 01$ & $<, 01$ & $<, 05$ & $<, 05$ &, 81 &, 07 &, 99 \\
COR_C & $\rho$ & & - & 0,45 & 0,27 & 0,49 & 0,30 & 0,52 & $-0,19$ \\
& $p$ & & - & $<, 01$ &, 56 & $<, 05$ &, 22 & $<, 05$ &, 43 \\
TAI-W & $\rho$ & & & - & 0,76 & - & - & 0,83 & 0,64 \\
& $p$ & & & - & $<, 01$ & - & - & $<, 01$ & $<, 01$ \\
TAI-E & $\rho$ & & & & - & 0,83 & 0,64 & - & - \\
& $p$ & & & & - & $<, 01$ & $<, 01$ & - & - \\
\hline
\end{tabular}

Poznámka: COR_A = hladina kortizolu při vstupu do školy, COR_B = hladina kortizolu při iniciaci zátěžové situace, COR_C = hladina kortizolu po skončení zátěžové situace, TAI-W = kognitivní strach, TAl-E = emocionální strach, yes = úzkostní jedinci, no = neúzkostní jedinci. 


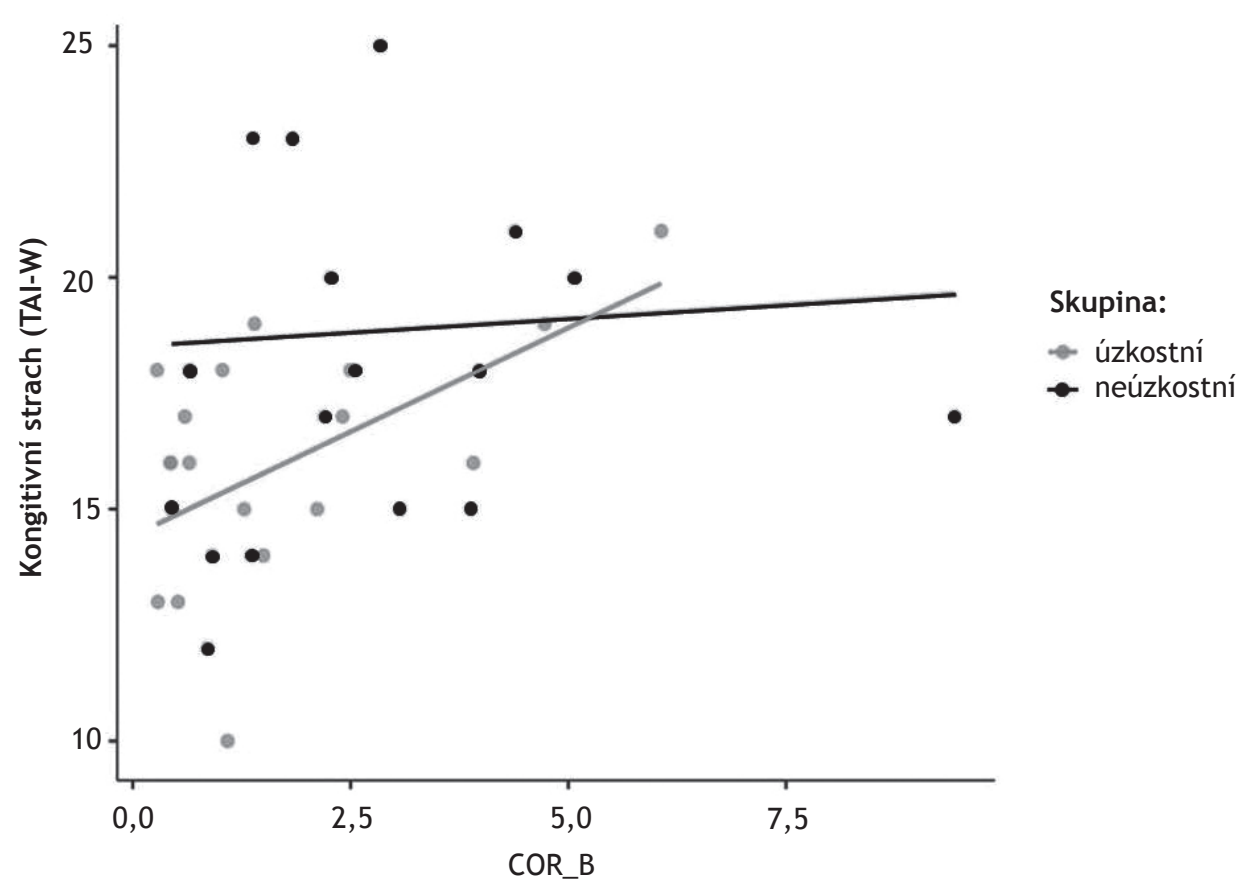

Obrázek 2 Vztah mezi kognitivním strachem (TAI-W) a hladinou kortizolu při iniciaci zátěžové situace (COR_B) u úzkostných a neúzkostných jedinců

\section{Diskuse}

Zaznamenaly jsme statisticky významný rozdíl mezi úzkostnými a neúzkostnými jedinci v hladině kortizolu naměřené při vstupu do školy. Zjištění, že se u úzkostných jedinců projevila prokazatelně nižší hladina kortizolu při příchodu do školy oproti jedincům neúzkostným, bylo v rozporu s očekáváním (Kapsdorfer et al., 2018; Shirtcliff \& Essex, 2008; Vaillancourt et al., 2008; West et al., 2010). Hypotézy 1a-c jsme proto zamítly. Naše výsledky dále do jisté míry podporují zjištění studií, které dokazují, že adolescenti vystavení v minulosti opakovanému negativnímu stresu vykazují nižší hladiny kortizolu než ti, kteři tak často stresovým situacím vystaveni nejsou (Hostinar \& Gunnar, 2013; Jaffee et al., 2015).

Vezmeme-li v úvahu, že sledované zátěžové situace jsou ve škole víceméně pro všechny žáky stejné, pak tedy rozdíly $v$ tom, jakým způsobem se $s$ nimi adolescenti vyrovnávají, jsou zřejmě ovlivněny řadou dalších faktorů, na které upozorňovaly i studie sledující souvislost mezi výkonem během zátěžové situace a produkcí kortizolu (Schultheiss et al., 2014; Yang et al., 2015). Tento jev však nebyl doposud uspokojivě vysvětlen. $O$ př́činách nelze $v$ současné chvíli relevantně diskutovat, ale hodláme se jim v budoucnu hlouběji věnovat. Hypoteticky lze předpokládat, že se 
96 hladina kortizolu pravděpodobně dlouhodobě formuje v souvislosti s typem situací, které jedinec prožívá, dále tím, jakým způsobem na ně reaguje, zvládá je a jak se získané zkušenosti promítají do jeho budoucích očekávání.

Další okruh hypotéz se týkal vývoje hladiny kortizolu u skupiny úzkostných a neúzkostných jedinců. Analyzovaly jsme, zda budou úzkostní a neúzkostní jedinci odlišně reagovat na zátěžovou situaci s hrozbou sociálního hodnocení (neohlášený test z matematiky). Sledovaly jsme vývoj hladiny kortizolu mezi prvním měřením při příchodu do školy $(A)$ a druhým a třetím měřením před a po zátěžové situaci $(B, C)$. Zjistily jsme, že zatímco u neúzkostných jedinců byla hladina kortizolu v zátěžové situaci $(B, C)$ významně nižší než při příchodu do školy $(A)$, u úzkostných jedinců tento pokles $v$ hladině kortizolu zaznamenán nebyl. Odlišnost vývojových trajektorií hladiny kortizolu u úzkostných a neúzkostných žáků byla prokázána analýzou rozptylu pro opakovaná měření, a hypotézu $\mathrm{H} 2$ proto můžeme přijmout - úzkostní a neúzkostní adolescenti se lišili v reakci na školní zátěžovou situaci. V tomto ohledu jsme ve shodě $s$ již uskutečněnými studiemi, které doložily, že je možné, že opakované vystavování se stresovým situacím přispívá $\mathrm{k}$ individuálním rozdílům v denních kortizolových rytmech u dětí a adolescentů (Lippold et al., 2016a; Lippold et al., 2016b; McHale et al., 2012).

Rovněž jsme zjišt’ovaly, zda hladina kortizolu souvisí s kognitivním a emocionálním strachem. Na celém souboru všech žáků (bez ohledu na míru úzkostnosti) jsme zaznamenaly středně silné a statisticky významné vztahy mezi hladinou kortizolu a kognitivním strachem, slabší vztahy pak byly potvrzeny mezi hladinou kortizolu a emocionálním strachem. Možné vysvětlení mưžeme hledat $v$ tom, že kognitivní stránka strachu (vtíravé myšlenky vztahující se k vlastnímu výkonu, obavy o dostatečnost vlastních schopností či obavy z důsledků vlastního selhání) více ovlivňuje výkon než stránka emocionální (Cassady, 2010), hladina kortizolu tedy vzrůstá spíše v souvislosti s kognitivním strachem než se strachem emocionálním (Jaffee et al., 2015; Peters et al., 2011). Specifická situace se však rýsuje s ohledem na žáky úzkostné, kteři vykazovali významné vazby mezi kortizolem a kognitivním a emocionálním strachem ve výkonové situaci B (zadání testu) i C (po skončení testu) na rozdíl od žáků neúzkostných, kteři v těchto situacích podobné vazby nevykazovali. Přijímáme tedy hypotézu $\mathrm{H} 3 \mathrm{~s}$ konstatováním, že kognitivní i emocionální strach má u úzkostných jedinců pozitivní vztah závislosti s výší kortizolové hladiny ve výkonové situaci, a to jak v okamžiku jejího zahájení, tak i po jejím skončení.

Provedené analýzy dále poukazují na to, že hladiny kortizolu jsou $v$ jednotlivých situacích odběru $(A, B, C)$ silně korelované. Je patrné, že jakmile kortizolová reakce nastoupí, má více tendenci vzrůstat, a naopak, čím nižší je kortizolová reakce při vstupu do školy, tím nižší hladiny kortizolu pak můžeme zaznamenat jak při zadávání testu, tak po jeho skončení. V našem výzkumu má kortizol u obou skupin úzkostných a neúzkostných adolescentů prokazatelně odlišný vývojový trend během dne (resp. $\checkmark$ reakci na zátěžovou situaci). Pokud hodnotíme reakce organismu na zátěžové situace, je nutné brát $v$ úvahu i tzv. copingové strategie (jakým způsobem jedinec obvykle reaguje na zátěžové situace a jak je zvládá), které jedinec $v$ reakci na typ 
sociální situace využívá. Typ strategie, kterou zvolí, je pak odvislý zejména od zku-

šenosti, kterou s podobnou situací měl, a od toho, jaké výsledky očekává v budoucnu v podobných situacích (Schultheiss et al., 2014; Yang et al., 2015).

Možným směrem uvažování ve zkoumání efektů nízké hladiny kortizolu u úzkostných jedinců by mohla být analýza účinků tzv. depersonalizace. Depersonalizace je známá zejména $v$ psychopatologii, kde se tento jev popisuje jako pocit nereálnosti, odloučení nebo bytí mimo jedince s ohledem na vlastní pocity a myšlenky (Schweden et al., 2018). Přestože se výzkum v oblasti depersonalizace zaměřuje na klinické poruchy, zkušenosti se neomezují pouze na akutní stavy duševních poruch, nebot' přechodné epizody depersonalizace jsou běžné v obecné populaci, především pokud jsou lidé pod negativním sociálním stresem (Hoyer et al., 2013). Někteří autoři popisují depersonalizaci jako druh reakce, která slouží jako funkční alternativa reakce na úzkost (Stein \& Simeon, 2009). Klasičtí psychoanalytičtí autoři popsali zkušenost depersonalizace jako mechanismus adaptace na situaci, kdy se jedinec oddělením emocí a chování vypořádává s jinak pro něj ohrožujícími emocionálními a fyzicky nepřijemnými pocity (Jacobson, 1959). Depersonalizace tedy jako forma copingové strategie může souviset s odlišným trendem změn hladin kortizolu u obou sledovaných skupin.

Testování (at' už ústní, nebo písemné) ve škole je situace se silnou hrozbou sociálního hodnocení, ve které je jedinec nucen setrvat a přizpůsobit se jí. Lze říci, že v situaci, ze které nemá jedinec možnost úniku či jiné kompenzační reakce, využívá naučené copingové strategie, které mu ji pomáhají zvládnout. Neúzkostní adolescenti dokážou zátěžovou situaci aktivně zvládat (Häusser et al., 2011; Schultheiss et al., 2014; Yang et al., 2015), což se v naší studii mohlo projevit právě snižováním hladin kortizolu ve slinách neúzkostných žáků, zatímco u žáků s tendencí k úzkostnému prožívání taková reakce nenastala. Úzkostní jedinci mají tedy zřejmě vypěstované takové strategie, kdy ve výkonové situaci přerozdělují či selektivně přenáší svoji pozornost mezi zaměřením na výkon a zaměřením na sebe sama ve snaze oslabit vlastní negativní emoční prožívání (tj. strach z negativního sociálního hodnocení).

\subsection{Limity a prognózy výzkumu}

Hlavní zdroj omezení v naší studii představuje menší výzkumný vzorek, který představovali žáci odpovídajícího věku ze čtyř základních škol. Významným limitem výzkumu byla také nemožnost zcela přesného dodržení odběru ve stejném čase po probuzení, protože se ráno hladiny kortizolu mění dynamičtěji než v průběhu dne. Zátěžová situace trvala 30 minut, její předpokládaný aktivační účinek na sekreci hladiny kortizolu nemusel nastat hned, ale až o 15 minut později. Limitem výzkumu může být i počet a výběr sledovaných situací, ve kterých byla hodnocena hladina kortizolu. Důležitým limitem výzkumu je to, že nebylo možné identifikovat genezi vzniku úzkostného prožívání u jednotlivých probandů, např. zda se jednalo o prríčinu genetickou, či získanou.

Možnosti rozšíření výzkumu spatřujeme ve sledování reakcí úzkostných a neúzkostných žáků v celé řadě dalších školních situací spojených s hrozbou sociálního 
98 hodnocení, např. při sledování hladiny kortizolu v situaci veřejné prezentace žáka (ústní zkoušení, předvedení motorické dovednosti apod.). Ukázalo se také, že by bylo vhodné vedle rysové úzkostnosti, strachu a kortizolu zjišt'ovat i další proměnné, kupř. copingové strategie, které mohou ovlivňovat biologickou reakci jedince na zátěžovou situaci. Přestože je představený výzkum pilotní, spatřujeme v něm značný výzkumný potenciál. Zkoumáním fyziologické báze reakcí jedince ve specifických podmínkách a situacích můžeme obohatit jak stávající teoreticko-výzkumné koncepce $v$ této oblasti, tak přinést mnohá doporučení pro českou pedagogickou praxi.

\section{Závěr}

Vysoká či zvýšená hladina kortizolu je obecně interpretována jako obranná reakce člověka na zátěžovou situaci. Naše studie poukázala na vazby mezi hladinou kortizolu a kognitivním či emocionálním strachem. Kognitivní i emocionální strach měl u úzkostných jedinců pozitivní vztah závislosti s výší hladiny kortizolu při iniciaci výkonové situace i po skončení testu. Neočekávaný (tj. předem neoznámený) test byl jedinci s tendencí k úzkostnému prožívání vnímán jako situace s hrozbou negativního sociálního hodnocení, což se patrně odrazilo ve změně hladin kortizolu. Žáci neúzkostní vykázali vysokou hladinu kortizolu při vstupu do školy významně související s jejich kognitivním strachem ze samotné školy vůbec. Zátěžová situace u neúzkostných jedinců nevyvolala významný kognitivní či emocionální strach a byla mj. spojena s poklesem hladin kortizolu. Na základě nalezených odlišností v hladinách kortizolu analyzovaných během potenciálně zátěžové situace ve škole u jedinců úzkostných a neúzkostných konstatujeme, že existuje souvislost mezi tendencí jedince k úzkostnému prožívání a změnami v hladinách kortizolu.

Zjištění, která studie přinesla, jsou sice vzhledem k rozsahu studie orientační, nicméně poskytla zajímavý náhled do problematiky školního strachu a rysové úzkosti tím, že se je snažila provázat s fyziologickou reakcí jedince. Sledovat tyto souvislosti má význam zejména pro pochopení žákovských postojů ke škole a jejich reakcí na situace spjaté s výkonem. Porozumíme-li podstatě dané reakce na určitý podnět i na její biologické bázi, pak se můžeme o to efektivněji zamýšlet nad tím, jak ji ovlivnit, jak s ní pracovat. Např́klad jak motivovat rysově úzkostné žáky ve výuce, jak podnítit jejich výkonovou motivaci či jak je naučit efektivním vzorcům chování na situace spojené s hrozbou sociálního hodnocení. Tyto předpoklady však budou muset být v budoucnu potvrzeny dalšími výzkumy. 


\section{Literatura}

Ahnert, L., Harwardt-Heinecke, E., Kappler, G., Eckstein-Madry, T., \& Milatz, A. (2012). Student-teacher relationships and classroom climate in first grade: How do they relate to students' stress regulation? Attachment \& Human Development, 14(3), 249-263. https: // doi.org/10.1080/14616734.2012.673277

Boyce, W. T., \& Ellis, B. J. (2005). Biological sensitivity to context: I. An evolutionary-developmental theory of the origins and functions of stress reactivity. Development and Psychopathology, 17(2), 271-301. https://doi.org/10.1017/S0954579405050145

Cassady, J. C. (2004a). The impact of cognitive test anxiety on text comprehension and recall in the absence of external evaluative pressure. Applied Cognitive Psychology, 18(3), 311-325. https://doi.org/10.1002/acp.968

Cassady, J. C. (2004b). The influence of cognitive test anxiety across the learning-testing cycle. Learning and Instruction, 14(6), 569-592. https://doi.org/10.1016/j.learninstruc.2004.09.002

Cassady, J. C. (2010). Anxiety in schools: The causes, consequences, and solutions for academic anxieties (Vol. 2). New York: Peter Lang.

Dabbs, J. M., Jr. (1991). Salivary testosterone measurements: Collecting, storing, and mailing saliva samples. Physiology \& Behavior, 49(4), 815-817. https://doi.org/10.1016/0031-9384 (91)90323-G

DeCaro, M. S., Thomas, R. D., Albert, N. B., \& Beilock, S. L. (2011). Choking under pressure: Multiple routes to skill failure. Journal of Experimental Psychology: General, 140(3), 390-406. https://doi.org/10.1037/a0023466

Dull, R. B., Schleifer, L. L. F., \& McMillan, J. J. (2015). Achievement goal theory: The relationship of accounting students' goal orientations with self-efficacy, anxiety, and achievement. Accounting Education, 24(2), 152-174. https://doi.org/10.1080/09639284.2015.10 36892

Ellenbogen, M. A., \& Hodgins, S. (2009). Structure provided by parents in middle childhood predicts cortisol reactivity in adolescence among the offspring of parents with bipolar disorder and controls. Psychoneuroendocrinology, 34(5), 773-785. https://doi.org/10.1016 /j.psyneuen.2008.12.011

Ellis, B. J., Essex, M. J., \& Boyce, W. T. (2005). Biological sensitivity to context: II. Empirical explorations of an evolutionary-developmental theory. Development and Psychopathology, 17(2), 303-328. https://doi.org/10.1017/S0954579405050157

Gordis, E. B., Granger, D. A., Susman, E. J., \& Trickett, P. K. (2006). Asymmetry between salivary cortisol and alpha-amylase reactivity to stress: Relation to aggressive behavior in adolescents. Psychoneuroendocrinology, 31(8), 976-987. https://doi.org/10.1016/j.psyneuen .2006 .05 .010

Gunnar, M. R., Frenn, K., Wewerka, S. S., \& Van Ryzin, M. J. (2009). Moderate versus severe early life stress: Associations with stress reactivity and regulation in 10-12-year-old children. Psychoneuroendocrinology, 34(1), 62-75. https://doi.org/10.1016/j.psyneuen .2008.08.013

Häusser, J. A., Mojzisch, A., \& Schulz-Hardt, S. (2011). Endocrinological and psychological responses to job stressors: An experimental test of the job demand-control model. Psychoneuroendocrinology, 36(7), 1021-1031. https://doi.org/10.1016/j.psyneuen.2010.12.016

Hellhammer, D. H., Wüst, S., \& Kudielka, B. M. (2009). Salivary cortisol as a biomarker in stress research. Psychoneuroendocrinology, 34(2), 163-171. https://doi.org/10.1016/j.psyneuen .2008.10.026

Hembree, R. (1988). Correlates, causes, effects, and treatment of test anxiety. Review of Educational Research, 58(1), 47-77. https://doi.org/10.3102/00346543058001047

Hostinar, C. E., \& Gunnar, M. R. (2013). Future directions in the study of social relationships as regulators of the HPA axis across development. Journal of Clinical Child \& Adolescent Psychology, 42(4), 564-575. https://doi.org/10.1080/15374416.2013.804387 
100 Hoyer, J., Braeuer, D., Crawcour, S., Klumbies, E., \& Kirschbaum, C. (2013). Depersonalization/derealization during acute social stress in social phobia. Journal of Anxiety Disorders, 27(2), 178-187. https://doi.org/10.1016/j.janxdis.2013.01.002

Hrabal, V., \& Pavelková, I. (2010). Jaký jsem učitel. Praha: Portál.

Chiang, J. J., Tsai, K. M., Park, H., Bower, J. E., Almeida, D. M., Dahl, R. E., ... \& Fuligni, A. J. (2016). Daily family stress and HPA axis functioning during adolescence: The moderating role of sleep. Psychoneuroendocrinology, 71, 43-53. https://doi.org/10.1016/j.psyneuen .2016 .05 .009

Jacobson, E. (1959). Depersonalization. Journal of the American Psychoanalytic Association, 7(4), 581-610. https://doi.org/10.1177/000306515900700401

Jaffee, S. R., McFarquhar, T., Stevens, S., Ouellet-Morin, I., Melhuish, E., \& Belsky, J. (2015). Interactive effects of early and recent exposure to stressful contexts on cortisol reactivity in middle childhood. Journal of Child Psychology and Psychiatry, 56(2), 138-146. https: // doi.org/10.1111/jcpp. 12287

Kaplan, D. S., Liu, R. X., \& Kaplan, H. B. (2005). School related stress in early adolescence and academic performance three years later: The conditional influence of self expectations. Social Psychology of Education, 8(1), 3-17. https://doi.org/10.1007/s11218-004-3129-5

Kapsdorfer, D., Hlavacova, N., Vondrova, D., Argalasova, L., Sevcikova, L., \& Jezova, D. (2018). Neuroendocrine response to school load in prepubertal children: Focus on trait anxiety. Cellular and Molecular Neurobiology, 38(1), 155-162. https://doi.org/10.1007/ s10571-017-0544-7

Khalaila, R. (2015). The relationship between academic self-concept, intrinsic motivation, test anxiety, and academic achievement among nursing students: Mediating and moderating effects. Nurse Education Today, 35(3), 432-438. https://doi.org/10.1016/j.nedt .2014.11.001

Kirschbaum, C., Pirke, K.-M., \& Hellhammer, D. H. (1993). The „Trier Social Stress Test'- a tool for investigating psychobiological stress responses in a laboratory setting. Neuropsychobiology, 28(1-2), 76-81. https://doi.org/10.1159/000119004

Kubikova, K., Bohacova, A., Lukavska, K., Mainz, D., \& Svobodova, S. (2018). Test Anxiety Inventory (TAl): Validization and psychometric properties of Czech version. Intcess $2018-5^{\text {th }}$ International Conference on Education and Social Sciences, 167-175.

Kuhlman, K. R., Robles, T. F., Dickenson, L., Reynolds, B., \& Repetti, R. L. (2019). Stability of diurnal cortisol measures across days, weeks, and years across middle childhood and early adolescence: Exploring the role of age, pubertal development, and sex. Psychoneuroendocrinology, 100, 67-74. https://doi.org/10.1016/j.psyneuen.2018.09.033

Lippold, M. A., Davis, K. D., McHale, S. M., Buxton, O. M., \& Almeida, D. M. (2016a). Daily stressor reactivity during adolescence: The buffering role of parental warmth. Health Psychology, 35(9), 1027-1035. https://doi.org/10.1037/hea0000352

Lippold, M. A., McHale, S. M., Davis, K. D., Almeida, D. M., \& King, R. B. (2016b). Experiences with parents and youth physical health symptoms and cortisol: A daily diary investigation. Journal of Research on Adolescence, 26(2), 226-240. https://doi.org/10.1111/jora .12186

Lisonbee, J. A., Mize, J., Payne, A. L., \& Granger, D. A. (2008). Children's cortisol and the quality of teacher-child relationships in child care. Child Development, 79(6), 1818-1832. https://doi.org/10.1111/j.1467-8624.2008.01228.x

Lowe, P. A., Ang, R. P., \& Loke, S. W. (2011). Psychometric analyses of the Test Anxiety Scale for Elementary Students (TAS-E) scores among Singapore primary school students. Journal of Psychopathology and Behavioral Assessment, 33(4), 547-558. https://doi.org/10.1007 /s10862-011-9250-9

Ly, J., McGrath, J. J., \& Gouin, J.-P. (2015). Poor sleep as a pathophysiological pathway underlying the association between stressful experiences and the diurnal cortisol profile among children and adolescents. Psychoneuroendocrinology, 57, 51-60. https://doi .org/10.1016/j.psyneuen.2015.03.006 
McHale, S. M., Blocklin, M. K., Walter, K. N., Davis, K. D., Almeida, D. M., \& Klein, L. C. (2012).

The role of daily activities in youths' stress physiology. Journal of Adolescent Health, 51(6), 623-628. https: //doi.org/10.1016/j.jadohealth.2012.03.016

Oberle, E., \& Schonert-Reichl, K. A. (2016). Stress contagion in the classroom? The link between classroom teacher burnout and morning cortisol in elementary school students. Social Science \& Medicine, 159, 30-37. https: / / doi.org/10.1016/j.socscimed.2016.04.031

Orel, M., Obereignerů, R., Reiterová, E., Malůš, M., \& Fac, O. (2015). Rozdíly sebepojetí u dětí a adolescentů České republiky podle pohlaví a věku. Psychologie a její kontexty, 6(2), 65-77.

Pendry, P., \& Adam, E. K. (2007). Associations between parents' marital functioning, maternal parenting quality, maternal emotion and child cortisol levels. International Journal of Behavioral Development, 31(3), 218-231. https://doi.org/10.1177/0165025407074634

Peters, E., Riksen-Walraven, J. M., Cillessen, A. H., \& de Weerth, C. (2011). Peer rejection and HPA activity in middle childhood: Friendship makes a difference. Child Development, 82(6), 1906-1920. https://doi.org/10.1111/j.1467-8624.2011.01647.x

Piers, E. V., \& Harris, D. B. (1964). Age and other correlates of self-concept in children. Journal of Educational Psychology, 55(2), 91-95. https://doi.org/10.1037/h0044453

Piers, E. V., \& Herzberg, D. S. (2002). Piers-Harris 2. Piers-Harris Children's Self-Concept Scale $\left(2^{\text {nd }} e d.\right)$. Los Angeles, CA: Western Psychological Services.

Putwain, D. W. (2008). Deconstructing test anxiety. Emotional and Behavioural Difficulties, 13(2), 141-155. https://doi.org/10.1080/13632750802027713

R Core Team (2018). R: A language and environment for statistical computing. [Computer software]. Vienna: R Foundation for Statistical Computing. https://cran.r-project.org

Ramirez, G., \& Beilock, S. L. (2011). Writing about testing worries boosts exam performance in the classroom. Science, 331(6014), 211-213. https://doi.org/10.1126/science.1199427

Repetti, R. L., Robles, T. F., \& Reynolds, B. (2011). Allostatic processes in the family. Development and Psychopathology, 23(3), 921-938. https://doi.org/10.1017/S095457941100040X

Repetti, R. L., Taylor, S. E., \& Seeman, T. E. (2002). Risky families: Family social environments and the mental and physical health of offspring. Psychological Bulletin, 128(2), 330-366. https://doi.org/10.1037/0033-2909.128.2.330

Ringeisen, T., \& Raufelder, D. (2015). The interplay of parental support, parental pressure and test anxiety - gender differences in adolescents. Journal of Adolescence, 45, 67-79. https://doi.org/10.1016/j.adolescence.2015.08.018

Sapolsky, R. M. (2002). Endocrinology of the stress-response. In J. B. Becker, S. M. Breedlove, D. Crews, \& M. M. McCarthy (Eds.), Behavioral endocrinology (s. 409-450). London: MIT Press.

Senka, J. (1994). Osobnostný dotazník pre deti B-JEPI. Bratislava: Psychodiagnostika.

Shirtcliff, E. A., \& Essex, M. J. (2008). Concurrent and longitudinal associations of basal and diurnal cortisol with mental health symptoms in early adolescence. Developmental Psychobiology, 50(7), 690-703. https://doi.org/10.1002/dev.20336

Schnell, K., Ringeisen, T., Raufelder, D., \& Rohrmann, S. (2015). The impact of adolescents' self-efficacy and self-regulated goal attainment processes on school performance - do gender and test anxiety matter? Learning and Individual Differences, 38, 90-98. https:// doi.org/10.1016/j.lindif.2014.12.008

Schultheiss, O. C., Wiemers, U. S., \& Wolf, O. T. (2014). Implicit need for achievement predicts attenuated cortisol responses to difficult tasks. Journal of Research in Personality, 48, 84-92. https://doi.org/10.1016/j.jrp.2013.10.004

Schweden, T. L., Wolfradt, U., Jahnke, S., \& Hoyer, J. (2018). Depersonalization under academic stress: Frequency, predictors, and consequences. Psychopathology, 51(4), 252-261. https: //doi.org/10.1159/000489468

Sladek, M. R. \& \& Doane, L. D. (2015). Daily diary reports of social connection, objective sleep, and the cortisol awakening response during adolescents' first year of college. Journal of Youth and Adolescence, 44(2), 298-316. https://doi.org/10.1007/s10964-014-0244-2 
Slatcher, R. B., \& Robles, T. F. (2012). Preschoolers' everyday conflict at home and diurnal cortisol patterns. Health Psychology, 31(6), 834-838. https://doi.org/10.1037/a0026774

Sommer, M., \& Arendasy, M. E. (2014). Comparing different explanations of the effect of test anxiety on respondents' test scores. Intelligence, 42, 115-127. https://doi.org/10.1016 /j.intell.2013.11.003

Spielberger, C. D. (1980). Test Anxiety Inventory (“Test Attitude Inventory”) (TAI). Redwood City: Consulting Psychologists Press.

Stein, D. J., \& Simeon, D. (2009). Cognitive-affective neuroscience of depersonalization. CNS Spectrums, 14(9), 467-471. https://doi.org/10.1017/S109285290002352X

Svoboda, M., Krejčířová, D., \& Vágnerová, M. (2015). Psychodiagnostika dětí a dospívajících. Praha: Portál.

The jamovi project (2019). jamovi (Version 1.0) [Computer Software]. https: / /www.jamovi.org

Thomas, C. R., \& Gadbois, S. A. (2007). Academic self-handicapping: The role of self-clarity and students' learning strategies. British Journal of Educational Psychology, 77(1), 101-119. https://doi.org/10.1348/000709905X79644

Thompson, R. A. (2014). Stress and child development. The Future of Children, 24(1), 41-59. https://doi.org/10.1353/foc.2014.0004

Vaillancourt, T., Duku, E., Decatanzaro, D., Macmillan, H., Muir, C., \& Schmidt, L. A. (2008). Variation in hypothalamic-pituitary-adrenal axis activity among bullied and non-bullied children. Aggressive Behavior, 34(3), 294-305. https://doi.org/10.1002/ab.20240

von der Embse, N., Jester, D., Roy, D., \& Post, J. (2018). Test anxiety effects, predictors, and correlates: A 30-year meta-analytic review. Journal of Affective Disorders, 227, 483-493. https: //doi.org/10.1016/j.jad.2017.11.048

West, P., Sweeting, H., Young, R., \& Kelly, S. (2010). The relative importance of family socioeconomic status and school-based peer hierarchies for morning cortisol in youth: An exploratory study. Social Science \& Medicine, 70(8), 1246-1253. https://doi.org/10.1016 /j.socscimed.2009.12.006

Windle, M., \& Windle, R. C. (2006). Adolescent temperament and lifetime psychiatric and substance abuse disorders assessed in young adulthood. Personality and Individual Differences, 41(1), 15-25. https://doi.org/10.1016/j.paid.2006.01.005

Yang, F., Ramsay, J. E., Schultheiss, O. C., \& Pang, J. S. (2015). Need for achievement moderates the effect of motive-relevant challenge on salivary cortisol changes. Motivation and Emotion, 39(3), 321-334. https://doi.org/10.1007/s11031-014-9465-7

Zeidner, M., Roberts, R. D., \& Matthews, G. (2008). The science of emotional intelligence: Current consensus and controversies. European Psychologist, 13(1), 64-78. https://doi .org/10.1027/1016-9040.13.1.64

Mgr. Kateřina Kubíková, Ph.D. (korespondenční autorka), katedra psychologie Fakulta pedagogická, Západočeská univerzita v Plzni Chodské náměstí 1, 30100 Plzeň kubikovk@kps.zcu.cz

doc. PhDr. Isabella Pavelková, CSc., katedra psychologie Pedagogická fakulta, Univerzita Karlova Myslíkova 7, 11000 Praha 1 e-mail: jfpavelka@volny.cz

Mgr. Aneta Boháčová, katedra psychologie Fakulta pedagogická, Západočeská univerzita v Plzni

Chodské náměstí 1,30100 Plzeň e-mail: bohacova@kps.zcu.cz 